\title{
PROTECTION AND CONCERVATION OF AGIA EIRINI GORGE GEOTOPE, WEST OF THE SAMARIA NATIONAL PARK, WESTERN CRETE
}

\author{
Bizoura A'., Manutsoglou $E^{2}$. \\ ${ }^{1} T e c h n i c a l$ University of Crete, Department of Mineral Resources Engineering, 73100 Chania, \\ Greece, katbizou@gmail.com, tel: 2821037652 \\ ${ }^{2}$ Technical University of Crete, Department of Mineral Resources Engineering, 73100 Chania, \\ Greece, emanout@mred.tuc.gr
}

\begin{abstract}
The unique in beauty and scientific interest geotope of Agia Eirini gorge is located at the western side of the White Mountains, in the Prefectural Administration of Chania. It is part of the European path $\mathrm{E} 4$, has a length of 7,5 kilometers and its northern entry is located at Agia Eirini village, $43 \mathrm{~km}$ far from Chania. It is part of the "Lefka Ori" Natura 2000 region (Code GR 4340008), part of the Samaria National Park and a Wild Life Shelter. The gorge crosses the metamorphic carbonate rocks of the Trypali Unit (age up to Middle Triassic) and the units of the Phyllite Nappe. The gorge represents a fault zone with a NNE - SSW direction, following the general direction of the large faults that cut the Mesozoic formations of the region. Along this path a lot of tectonic features can be regarded and studied, so the gorge can be characterized as a natural laboratory for the understanding of the terms fault and fault zone. In this study, using GIS, an information system for the gorge of Agia Eirini is organized and the combination of thematic maps revealed a delimitation problem of the protected area.
\end{abstract}

Key words: Natura 2000, GIS, geodiversity, delimitation

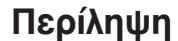

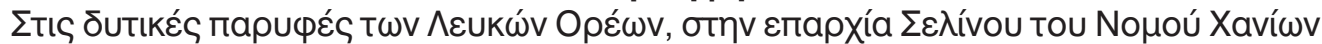

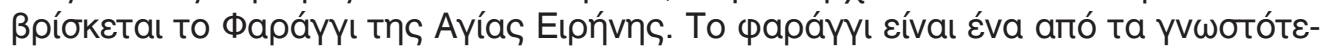



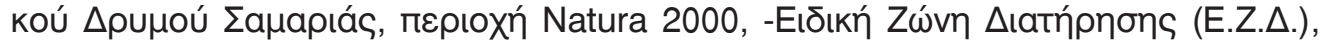





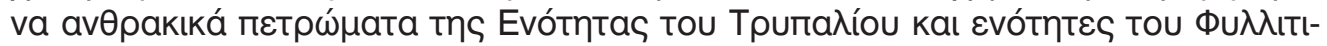

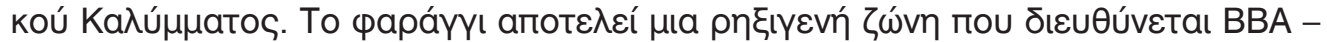

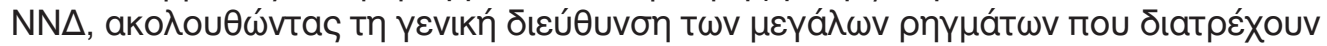

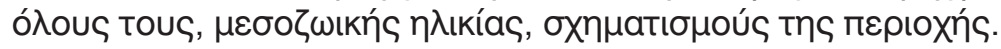

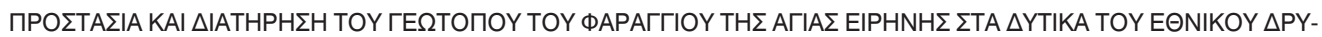
MOY SAMAPIAE, $\triangle$ YTIKH KPHTH

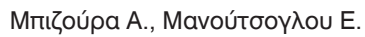




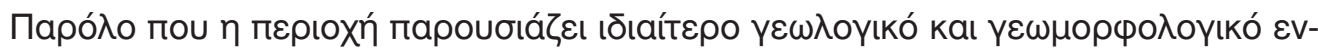

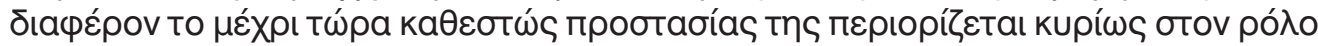

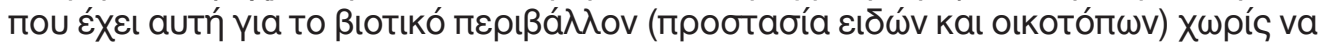



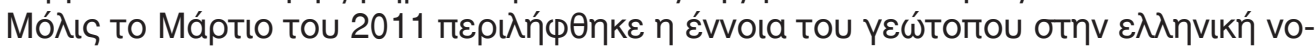

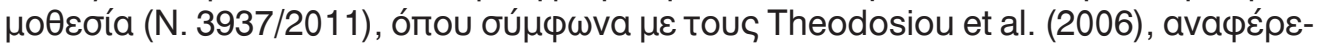

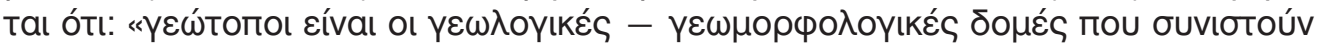



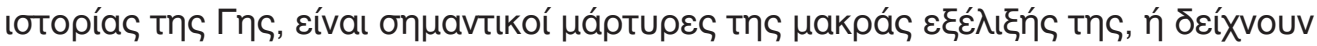
бúүXpoves

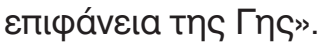

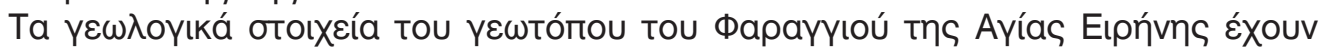

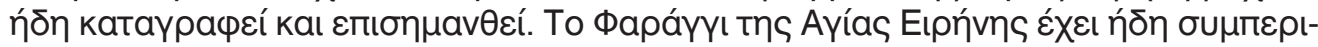

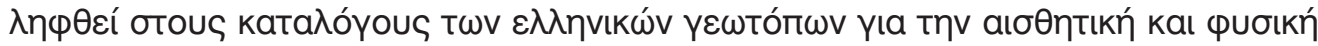

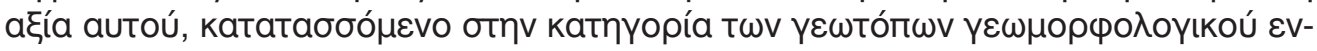

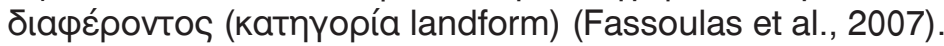

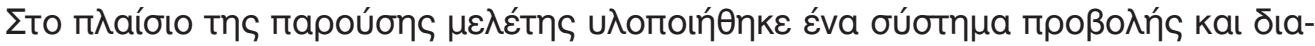

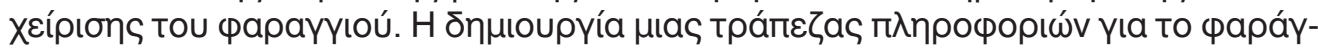

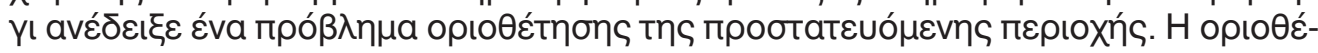

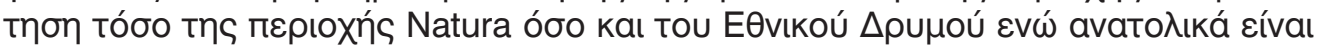



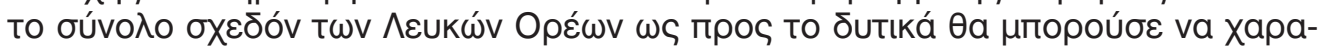

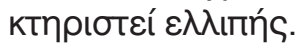

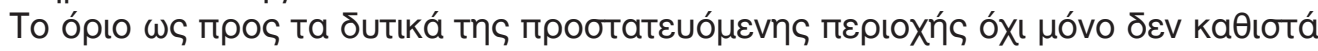

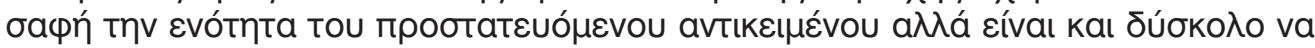

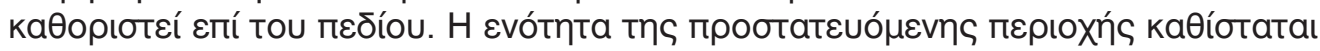

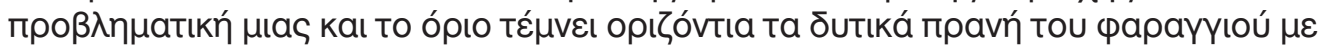

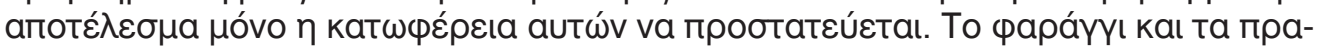



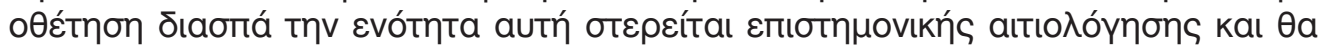

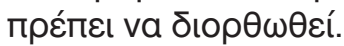

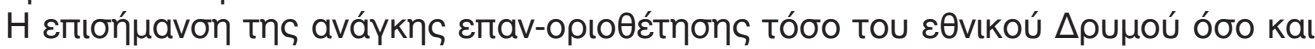

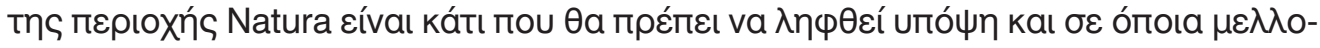

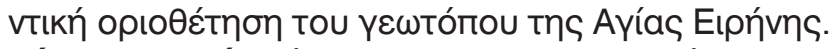

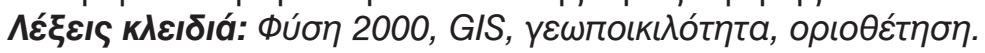

\section{Introduction}

Forty three kilometers southwest of Chania starts the gorge of Agia Eirini. The gorge is located on the west side of the White Mountains (Fig. 1). It belongs to the Municipality Kantanou-Selinou of the Prefectural Administration of Chania and it is named by the village of Agia Eirini, which is near the northern entry of the gorge. It consists of metamorphic carbonate rocks of the Trypali Unit, a formation of Triassic age, and the Phyllite unit formations. It is part of the European path $E 4$, has a length of 7,5 kilometers and is the second most visited gorge in Chania (with Samaria being the first one). The gorge is one of the most famous gorges of Crete and is a multi- 

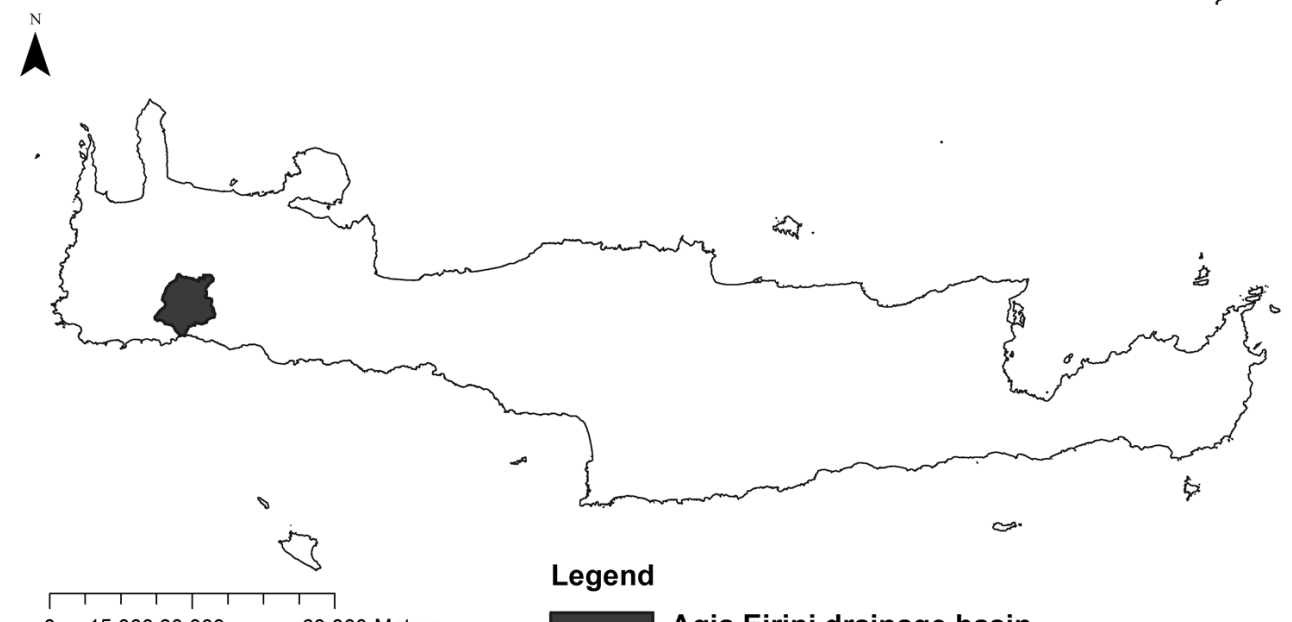

o $15.00030 .000 \quad 60.000$ Meters

Agia Eirini drainage basin

Fig. 1. Geographical position of the study area.

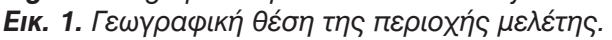

ply protected area (part of the "Samaria" National Park, "Natura 2000 Area", "Important Bird Area" (European Important Bird Area Programme - BirdLife International) and "Special Protection Area") (Directive 79/409/EEC, 2009/147/EC ). It is worth mentioning that it is accessible for a longer period (relatively to Samaria gorge), and it is a developing resource, since its use has begun recently. Also important is the role it could play in the management of National Park's visitors especially during the months with high traffic.

In recent years, the increasing development of Geographical Information Systems (GIS) has provided powerful tools for the collection, storage, analysis and presentation of geographically oriented data. Taking advantage of this technology a database for the gorge of Agia Eirini was set.

A series of primary spatial data on geology, topography, the river network, the land use and the protected areas in the region, were used to produce thematic maps. The combination of thematic maps revealed a problem of delineation of the protected area.

\section{Agia Eirini geotope}

\subsection{Geological setting}

The island of Crete is located north of the Hellenic trench. The geological framework consists largely of nappes of contrasting lithologies and metamorphism that were stacked southwards during an Oligocene to early Miocene N-S compression. Most of the whole nappe stack of continental Greece is recognized in Crete. The nappes are stacked from top to bottom, i.e. from the most internal to external units in the following order: Asterousia nappe, Miamou nappe, Arvi nappe, Pindos-Ethia nappe, Tripolitza nappe, Phyllite nappe and Trypali nappe. The Plattenkalk Group represents the lowermost known tectonic 
unit beneath the nappe pile of Crete and their formation has been involved in the tectonometamorphic process during the Oligocene-Miocene.

The complexity of the geological structure and access difficulties, due to the high topographical relief and thin infrastructure, are the main reasons that in Western Crete, the existing geological maps are dated back in the 1960's; whilst for some parts, as the area of Palaiochora the basic geological map has just been published. Although a number of geoscientists have worked and published papers regarding the wider area (e.g. Manutsoglu et al., 1999; 2001; 2003), the gorge in particular has recently become subject of systematic studies (Bizoura et al., 2004; 2006).

According to these researchers, on the map region, apart from the Quaternary and Neogene sequences, parts of the Tripolis series are found, consisting of Jurassic and Cretaceous limestone, eastern of the southern end of the gorge. On the northern and western part of the region, grey and white dolomitic marbles appear, containing a characteristic bituminous horizon of $2-3 m$ thickness, which are tectonically positioned over the underlying formations. The marbles are locally similar to the metamorphic carbonate of the Plattenkalk-Group, but without flints. These are the metamorphic carbonate of Trypali Unit, of no later than Middle Triassic (Creutzburg and Seidel, 1975) or Upper Triassic (Karakitsios, 1987) age, which are always thrusted over the Plattenkalk-Group (Pomoni and Karakitsios, 2002), but their paleogeographical position is unknown and has been subject of long scientific controversies.

The underlying unit is build by rocks of the Plattenkalk-Group. The first detailed lithostratigraphical description, which revised the dating on the geological map
(Carboniferous-Perm), was prepared by Fytrolakis (1980) and was supplemented by Soujon et al. (1998).

The wider research area is part of a mega-anticline of NNE-SSW direction, plunging to the NE that determined the morphotectonical evolution of the region during the Neogene and the Quaternary. The visible core of this structure is the Gigilos mountain peak, on the northern part of the Samaria gorge, which is build by the older rocks of the PlattenkalkGroup (Manutsoglou et al., 2003), above which Trypali Unit is overthrusted.

The Agia Eirini gorge evolved in this fractured metamorphic carbonate sequence of large thickness. In the I.G.M.E. geological map (Tataris et al., 1969), the gorge is shown to evolve entirely in the Trypali Unit metamorphic rocks (Fig. 2). However, field work revealed that also metamorphic rocks of the PlattenkalkGroup appear in the gorge, which are not shown in the map, probably due to its scale (1:50000). The appearance of the tectonically lower unit is of significant importance for the explanation of the formation of the gorge, which simply evolved along a fault zone. To exhibit all these data, a GIS database was built and a three dimensional morphotectonical - geological model has been constructed (Manutsoglou et al., 1999). The gorge represents a fault zone with a NNE - SSW direction, following the general direction of the large faults that cut the Mesozoic formations of the region. Along the path a lot of tectonic features can be regarded and studied, so the gorge can be characterized as a natural laboratory for the understanding of the terms fault and fault zone.

\subsection{Protection and conservation}

The gorge is a natural habitat of many species of wild fauna with Capra aega- 


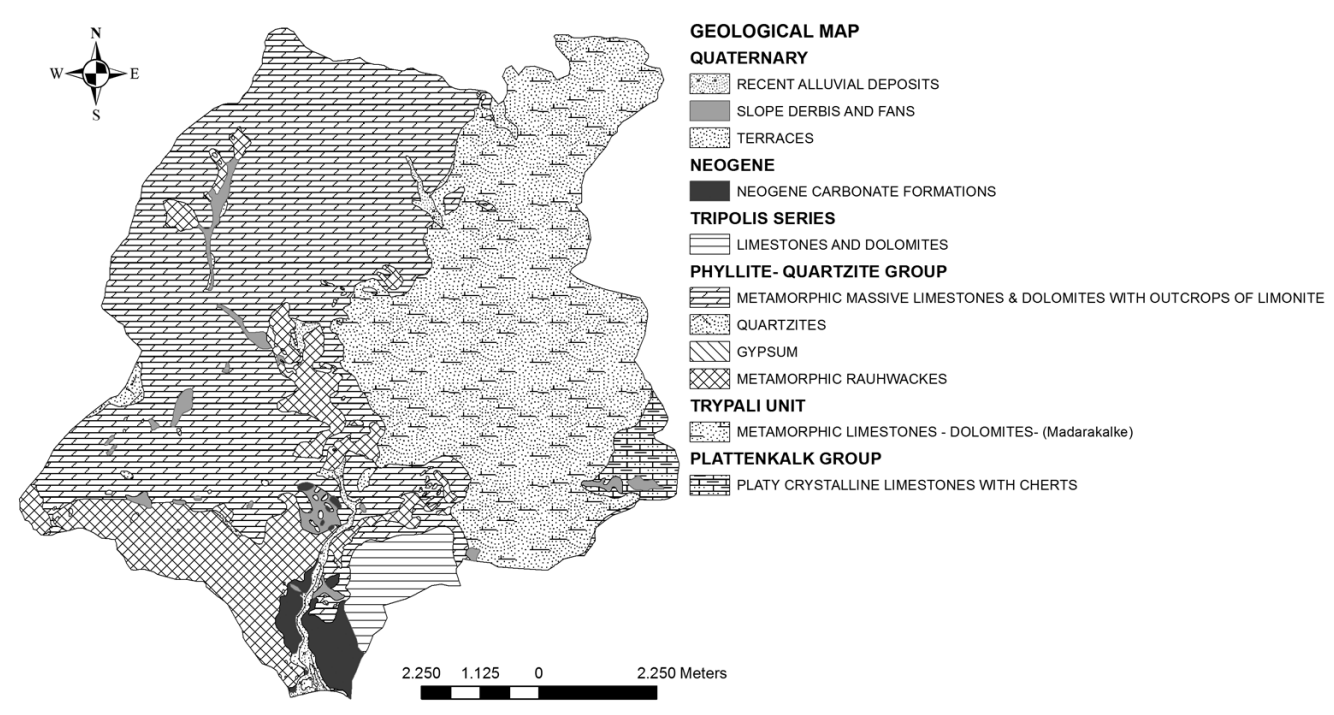

Fig. 2. Digitized geological map after Tataris et al. (1969) of Agia Eirini gorge drainage basin.

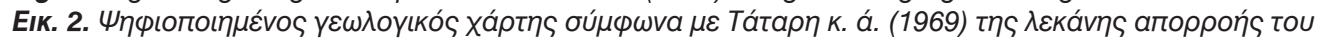

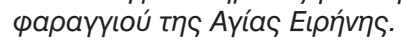

grus cretica being the most known of the protected ones. It is a habitat of many bird species also. Gypaetus barbatus, a rare predatory bird threatened with extinction, lives in the gorge

From the perspective of flora the gorge is characterized by high biodiversity with many species of trees and shrubs: $\mathrm{Cu}$ pressus sempervirens, Pinus brutia, Platanus orientalis, Acer creticus, Quercus coccifera, Ceratonia Siliqua, Vitex agnuscastus and many more. Very impressive is the variety of phrygana and aromatic species. Typical species here are Thymus capitatus, Salvia officinalis, Satureja thymbra, Ebenus cretica and the therapeutic Origanum dictamnus that grows on the steep slopes of the gorge and is one of the many endemic species found in the gorge.

The great ecological value of the gorge is accompanied by a rich and enduring cultural identity.
The signs of the presence of the recent liberation struggles are still apparent. The gorge was a base area for constant struggle against the Turks. The whole gorge and individual areas such as "Fygou" path, used to escape to Omalos plateau, women and children, chased by the Turkish occupation. Also various caves served as bases of operations such as "Choirotrypa", the ruined houses in "Polla Spitakia" and the "Porofarango" and they are important parts of the local history.

The gorge of Agia Eirini has already been included in the list of Cretan geotopes. It has been classified in the category of landforms with an aesthetic and natural value and of regional importance. In addition, the amount of the aforementioned tectonic features that are observed in the gorge could contribute to the understanding of the terms fault and fault zone. Nevertheless, the 
protection status so far is limited mainly to the biodiversity protection (protection of species and habitats) without regarding geodiversity protection issues.

Concerning the protection and conservation status of the Agia Eirini gorge:

- It is part of the Samaria National Park. With the Law 3044/2002 the Samaria Management Body was founded and the boundaries of the National Park were extended.

- Special Area of Conservation (SAC) of the Natura 2000 network, code GR4340008 «Lefka Ori kai paraktia zoni», (Directive 92/43/EEC, 2006/613/EC Commission Decision).

- Special Protection Area (SPA) «on the conservation of wild birds» directive, code GR4340014 «Ethnikos-Drymos Samarias - faragi Tripitis - Psilafi - Koustogerako", (Directive 79/409, 2009/147 EC).

- Wild Life Shelter, characterized by the Ministry of Rural Development and Food (Law No 177/75 as amended by Law No 2637/98)

Many decades of earth scientific research have led to the identification of many geological and geomorphological sites, having regional, national or international importance. In order to protect and conserve these sites as part of the natural heritage international organizations such as the International Union for the Conservation of Nature (IUCN), UNESCO and the International Union of Geo-Sciences (IUGS) have established certain initiatives to include geodiversity to nature conservation policies. More specific, UNESCO supports an initiative called Global Geoparks Network to enhance nationally the value of important geological sites, while IUGS together with ProGEO established in 1996 an initiative named Geosites to compile a global list of the world's most important ge- ological sites (Theodosiou et al., 2003; Murray, 2004; Theodosiou et al., 2006). While biological conservation has got a high standing in our country, geological conservation is considered still limited. Geological conservation is an issue not being dealt in a systematic way under Greek law. In the Greek territory there are many protected areas (National Parks, Aesthetic Forests, Natural Monuments). In all these areas the protection of the geological substratum is missing, as if it's not part of the nature (despite the fact that many of the important attractions are geomorphology or geology based). The Institute of Geology \& Mineral Exploration has begun many years ago, an effort for the registration, promotion, and protection of the geological and geomorphological heritage (Theodossiou-Drandaki et al., 1997a, Theodosiou, 2010). The first recording of representative geological and geomorphological sites as monuments of nature was undertaken by the Institute of Geology and Mineral Exploration (IGME) in 1982. (http://portal.igme.gr)

The first step has already been made and the Law about biodiversity (Law 3937/2011) includes the concept for the geological conservation in Greek legislation: In accordance with article 2 of L.3937/2011, "geotopes are geological - geomorphological structures that are natural formations, represent significant moments in geological history of the Earth and they are important witnesses of the long evolution or show recent physical, geological processes that continue to evolve in the Earth's surface".

IGME has implemented several projects aiming to promote geoconservation in Greece like Grecel project in 1996 (Theodosiou-Drandaki et al., 1997b; Drandaki et al., 1999) and "Geotrails in Greece" (Theodosiou et al., 2010). Agia Eirini 
gorge geotope is included in one of the "Geotrails in Greece" in West Crete (Geotrail 3: From Therissos to Agia Eirini gorge-Soughia), (http://old.igme.gr/GRgeotrails.htm). The geological data of the Agia Eirini geotope have already been recorded (Bizoura et al., 2004; 2006) and the gorge has been included to the Cretan geotopes database (Fassoulas et al., 2007).

\section{Data and results}

\subsection{Data}

The basic aim of this work was the compilation of a database for the Agia Eirini gorge

For the attainment of this aim, the following data were used:

- geological map, 1:50.000 scale (Alikianos sheet), by the Institute of Geology and Mineral Exploration (I.G.M.E.)

- topographical map, 1:50.000 scale (Vatolakkos sheet), by the Hellenic Military Geographical Service (H.M.G.S.)

- digital map of the Cretan region with 20 -meter elevation contours

- land use map, 1:100.000 scale of the European program CORINE land cover

- data and records acquired from field work conducted in the study area

- National Park Map and Natura 2000 maps, 1:50.000 scale

- Orthophoto maps (Ministry of Rural Development and Food, year 1998).

For the storage, processing and analysis of the primary data, the ArcGIS program of ESRI was used. With this software we set up a database for the study area. Besides primary data, the database includes secondary data as well, which were derived by the analysis and processing of the raw data and by all studies conducted in the area. The secondary data include the digitized geological map (which is supple- mented with details from field work), the digitized river network, the digital terrain model, the map of morphological gradients, maps of the hydrographic frequency and density etc. The combination of the above maps led to important conclusions about the protected area limits (Figs 3,4 ).

\subsection{Data analysis and results}

All spatial data concerning geology, topography, the river network, land use and the protected areas in the region, together with their attributes were used to create a geo-database. The integration of this information under a GIS assisted in the identification of a delimitation problem for the protected area.

Natura 2000 is a coherent European ecological network of special areas of conservation set up for the implementation of Directive 92/43/EEC. The aim of this Directive was to contribute towards ensuring bio-diversity through the conservation of natural habitats and of wild fauna and flora in the European territory of the Member States. The NATURA 2000 network is composed of sites hosting the natural habitat types and habitats of the species listed in Annexes I and II of the Directive. A Natura 2000 site is a geographically defined area whose extent is clearly allocated. The natural habitats of each site are distinguished by geographic, abiotic and biotic features. (Commission of Europe Communities (CEC), 1991; Council of Europe, 1992).

According to the maps of the protected areas (Figs $3,4,5)$ the delineation of the area is not clear and the habitats are not separated by a well-defined geographical boundary. From the eastern side of the gorge the delineation of the Natura 2000 and the National Park forms a continuous and unified entity with the gorge of Samaria and the White Mountains.

The west side does not share the same 


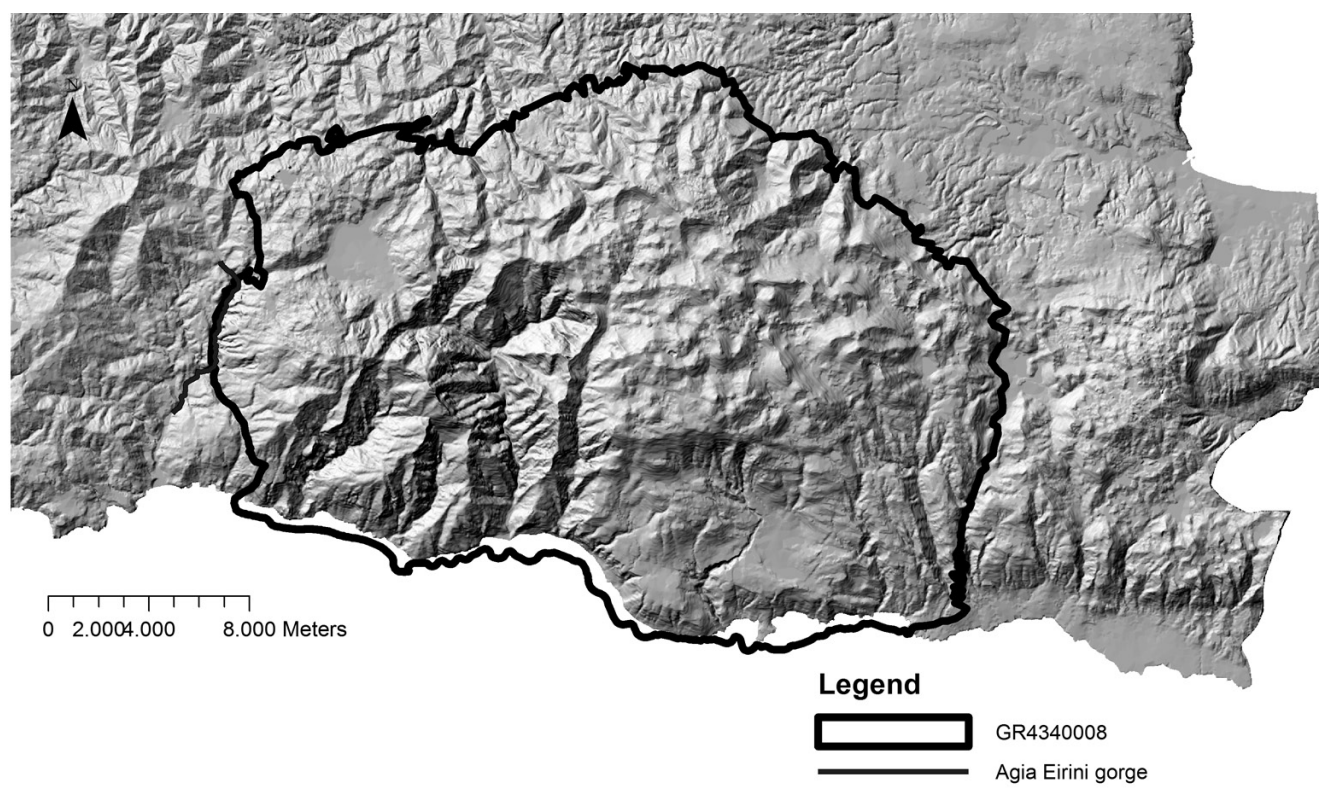

Fig. 3. Digital elevation model with Natura 2000 Gr 434008 «Lefka Ori kai paraktia zoni» area and the path through Agia Eirini Gorge.

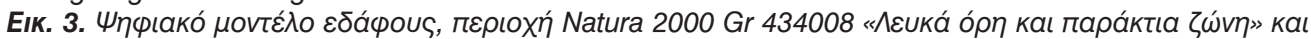

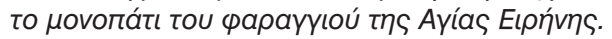

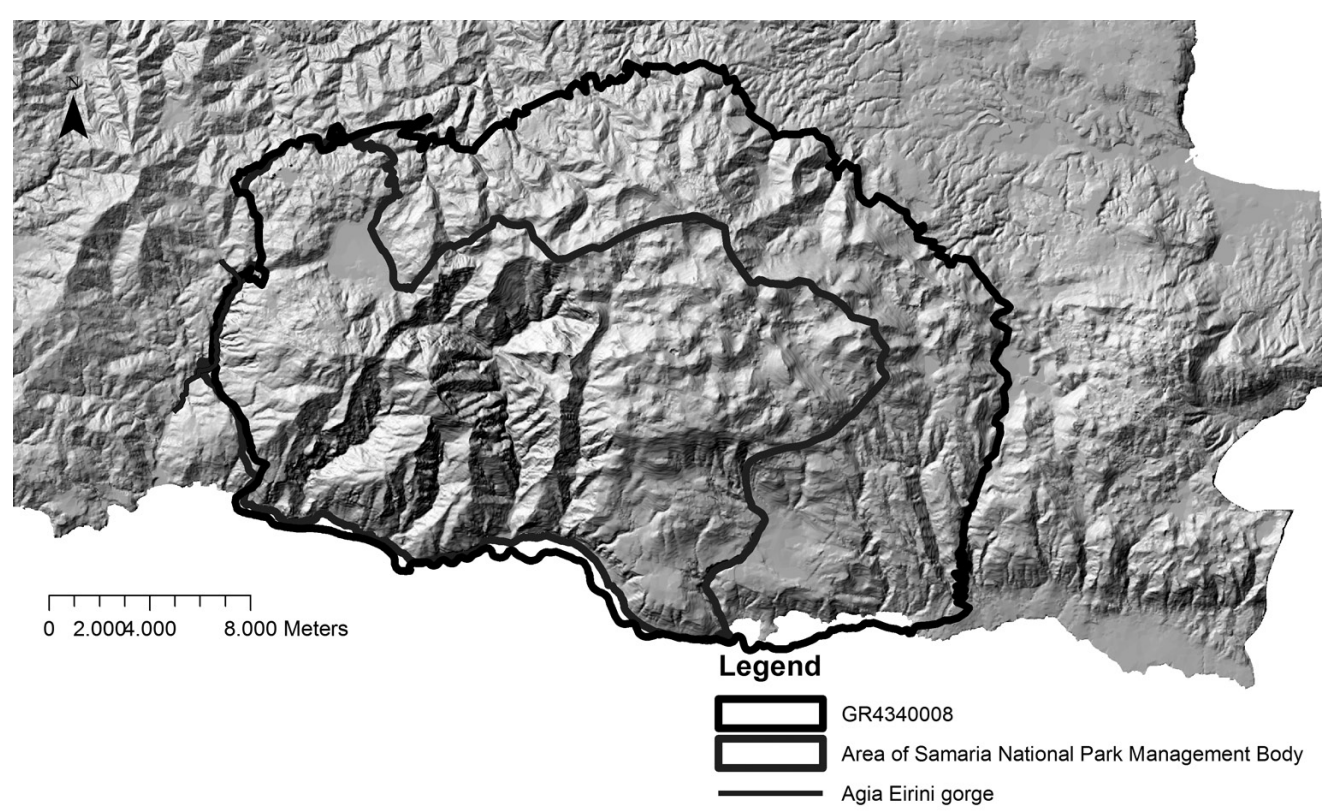

Fig. 4. Digital elevation model with Natura $2000 \mathrm{Gr} 434008$ «Lefka Ori kai paraktia zoni» area, the protected area of the Samaria National Park management body and the path through Agia Eirini Gorge.

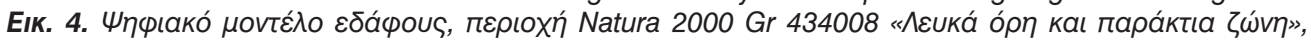

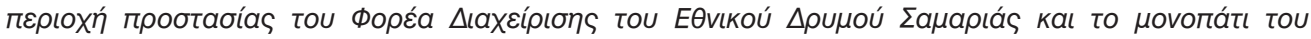

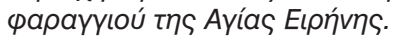




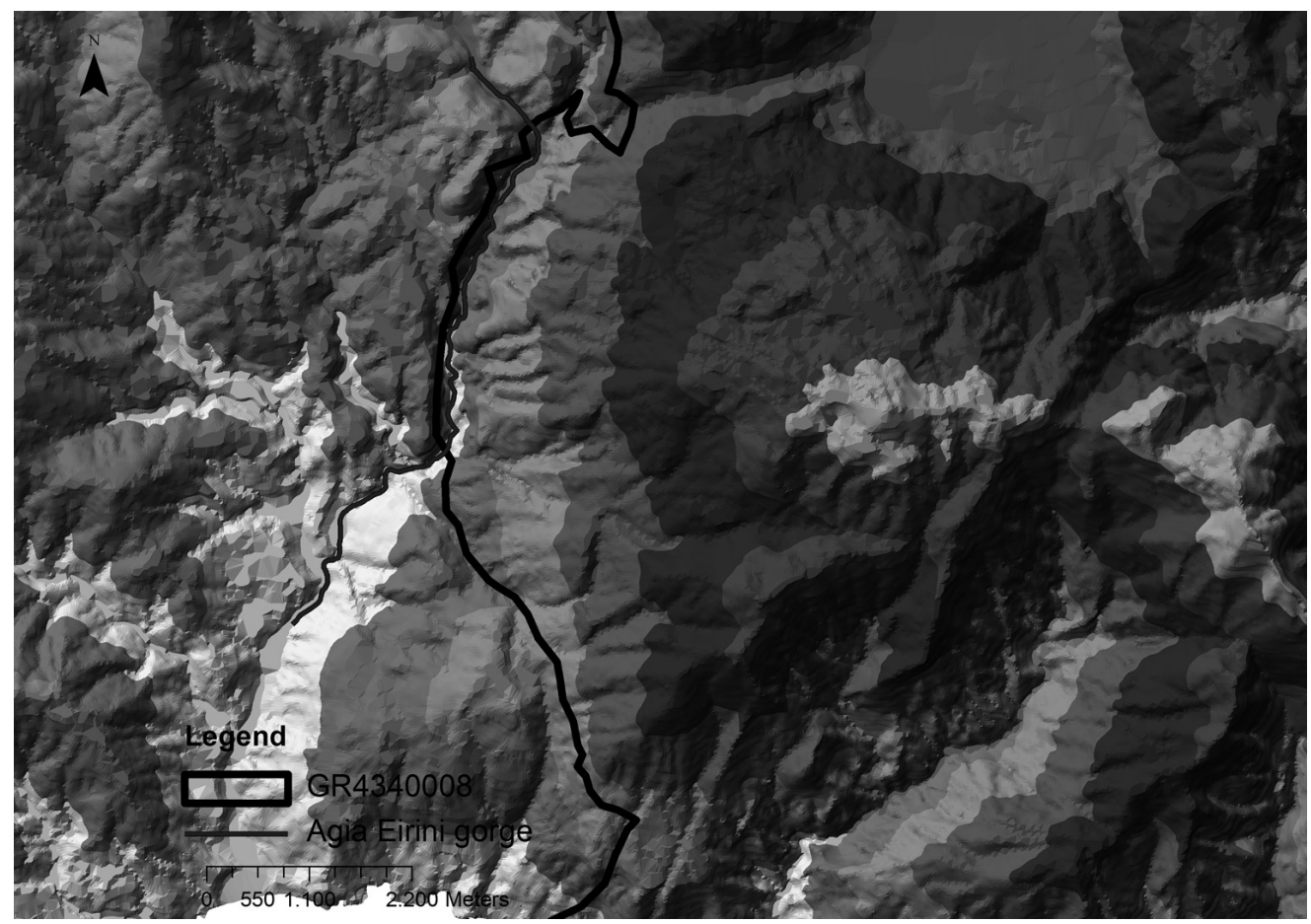

Fig. 5. Digital elevation model with Natura 2000 Gr 434008 «Lefka Ori kai paraktia zoni» area and the path through Agia Eirini Gorge (detail enhancement of the delineation problem).

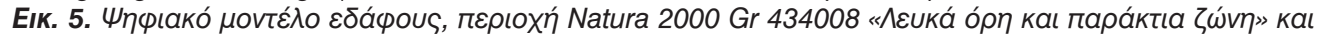

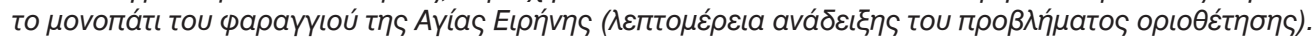

principles and its border could be described as incomplete. Additionally the west limit is difficult to be determined on the ground. The unity of the protected area is vague since the boundary intersects with the western slopes of the gorge leaving a small part of them under protection. The gorge and its slopes form a dynamic and interrelated system. Any division splitting this system lacks scientific justification and should be investigated. A review of the protected area boundaries is recommended. This correction concerns not only the Natura 2000 area but the National park as well. It is also indicated that apart from the need of re-demarcation in both the $\mathrm{Na}$ tional Park and the Natura 2000 area, this correction should be taken into account in any future delineation of the geotope of Agia Eirini.

\section{Conclusions}

Setting up a GIS database with the capability of spatial data storing, information integration and ease in future adjustments proves a powerful tool for the management and protection of Agia Eirini gorge geotope.

In this study, a geographical information system for the gorge of Agia Eirini is organized. The combination of the produced thematic maps revealed a delineation problem of the protected area. The west limit of the protected area intersects with the western slopes of the 
gorge so only part of them is protected. The correction of the geographical boundaries is important not only for the Natura 2000 area and the National Park but also for the geographical definition of the Agia Eirini geotope.

\section{References}

Bizoura, K., Manutsoglou, E., Spyridonos, E., 2004. Visualization with GIS of Agia Eirini gorge at the southern margins of the White Mountains. Bulletin of the Geological Society of Greece XXXVI/2, Proceedings of the 10th International Congress, Thessaloniki, 1018-1025.

Bizoura K., Manutsoglou, E., Spyridonos, E., 2006. Analogical and digital geological map of Agia Eirini gorge at the southern margins of the White Mountains, SW Crete. Proceedings of the 8th national Congress of Cartography, Thessaloniki, 459-468.

Council of Europe, 1992. Council Directive 92/43/EEC of 21 May 1992 on the conservation of natural habitats and of wild fauna and flora. CONSLEG: 1992 L0043.

Creutzburg, N., Seidel, E., 1975. Zum Stand der Geologie des Preaneogens auf Kreta. Neues Jahrbuch Geologie und Palaeontologie Abhandlunge., 198, 363-383.

Drandaki, I., Diakantoni, A., Eder, W., Fermeli, G., Galanakis, D., Gonggrijp, G.P., Hlad, B., Koutsouveli, A., Martini, G., Page, K., Patzak, M., 1999. GRECEL, Geological Heritage: Research in Environmental education and cooperation in European level. II International Symposium ProGEO on the Conservation of the Geological Heritage, Madrid, Spain - November 23-25/11/1999, 324-329.

European network on geoconcervation and geological heritage. International
Conference on Environment and Society: Education and Public Awareness for Sustainability, Thessaloniki, 8-12/12/97, Abstract v., 592-593.

Fassoulas, C., Paragamian, K., lliopoulos, G., 2007. Identification and assessment of Cretan Geotopes. Bulletin of the Geological Society of Greece, XXXVII, Athens, 1780 - 1795.

Fytrolakis, N., 1980. The geological structure of Crete. NTU Athens, $146 \mathrm{pp}$.

Gray, M., 2004, Geodiversity: Valuing and Conserving Abiotic Nature. Wiley, Chichester, 434pp.

Karakitsios, V., 1986. The lithostratigraphical, metamorphic and tectonic relations between Phyllite and Tripolis carbonate series in Middle-Western Crete. Bull. Geol. Soc. Greece, 28, 31-58.

Karakitsios, V., 1987. Sur la signification de la série de Trypali dans la région de Sellia en Crète occidentale (Grèce). CR Acad. Sci. Paris, 304 (II/3), 123-128.

Manutsoglou, E., Jacobshagen, V., Spyridonos, E., Skala, W., 1999. Geologische 3D-Modellierung der Plattenkalk-Gruppe West-Kretas (Erste Ergebnisse). Mathematische Geologie, 4, 73-79.

Manutsoglou, E., Spyridonos, E., Soujon, A., Jacobshagen, V., 2001. Revision of the geological map and $3 D$ modelling of the geological structure of the Samaria gorge region, W. Crete. Bulletin of the geological Society of Greece, XXXIV/1, 29-36.

Manutsoglou, E., Soujon, A., Jacobshagen, V., 2003. Tectonic structure and fabric developmant of the Plattenkalk unit around the Samaria gorge, Western Crete, Greece. Z. dt. geol. Ges., 154/1, 85-100.

Theodosiou, Ir., 2010. Designation of 
Geosites - proposals for Geoparks. Bulletin of the Geological Society of Greece, XLII/2, 926-938.

Theodosiou, Ir., Athanassouli, E., Epitropou, N., Janikian, Z., Kossiaris, G., Michail, K., Nikolaou, E., Papanikos, D., Paschos, P., Pavlidou, S., Vougioukalakis, G., 2010. Geotrails in Greece. Bulletin of the Geological Society of Greece, XLIII/2, 939-947.

Theodossiou-Drandaki, Ir., Fermeli, G., Koutsouveli, A., 1997b. Environmental Education Theodossiou-Drandaki, I., Nakov, R., Wimbledon, W.A.P., Serjani, A., Neziraj, A., Hallaci, H., Sijaric, G., Begovic, P., Petrussenko, Sv., Tchoumatchenco, PI., Todorov, T., Zagorchev, I., Antonov, M., Sinnyovski, D., Diakantoni, A., Fassoulas, Ch., Fermeli, G., Galanakis, D., Koutsouveli, A., Livaditi, A., Papadopoulou, K., Paschos, P., Rassiou, A., Skarpelis, N., Zouros, N., Grigorescu, D., Andrasanu, Al., Hlad, Br., Herlec, U., Kazanci, N., Saroglu, F., Dogan, A., Inaner, H., Dimitrijevic, M., Gavrilovic, D., Krstic B., Mijovic, D., 2003. IUGS Geosites project progress - a first attempt at a common framework list for South Eastern European Countries. In: Parkes, M.A. (Ed.), Natural and cultural Landscapes- the geological foundation.
Proceedings of a conference 9-11 September 2002. Dublin Castle. Ireland. Royal Irish Academy, 81-89.

Theodosiou, I., Fermeli, G., KoutsouveIi, An., 2006. Our Geological Heritage. Kaleidoskopio, Athnes, 104pp. (In Greek).

Theodosiou, I., Koutsouveli, A., loakim, C., 1997a. Geological geomorphological heritage - Geotopes. - In: Marinos, P., Koukis, G., Tsiabaos, G., Stournaras, G. (Eds), Engineering Geology and the Environment, 30213025.

Pomoni-Papaioannou, F., Karakitsios, V., 2002. Facies analysis of the Trypali carbonate unit (Upper Triassic) in central-western Crete (Greece): an evaporite formation transformed into solution-collapse breccias. Sedimentology, 49, 1113-1132.

Soujon, A., Jacobshagen, V., Manutsoglou, E., 1998. A lithostratigraphic correlation of the Plattenkalk occurrences of Crete (Greece). Bulletin of the geological Society of Greece, XXXII/1, 41-48.

Tataris, A., Christodoulou, G., 1969. Geological map of Greece, 1:50.000, Vatolakkos sheet", I.G.M.E., Athens.

http://old.igme.gr/GRgeotrails.htm http://portal.igme.gr 